\title{
THE IMPLEMENTATION OF COMMUNITY LANGUAGE LEARNING (CLL) IN TEACHING SPEAKING \\ (A Qualitative Study at One of Universities in Cianjur)
}

\author{
by \\ Asep Saepuloh, S.S.,M.Pd \\ azalia@yahoo.com \\ Suryakancana University
}

\begin{abstract}
Speaking is one of important aspects of language. Speaking plays an important role in transfering English speaking skill to students as well as the key to the success of teaching learning process of speaking. There are many methods or approaches used by lecturers in the classroom in teaching speaking in university, they however considered not so effective in stimulating students to be more active in speaking and to have more bravery and self confidence to use their own English although they may make more mistakes. Based on the depicted reality, the researcher feels chalenged to know how is the implementation of Community Language Learning (CLL) method, to investigate its strengths and weaknesses, as well as to find out students' difficulties in teaching s6peaking.

This research entitled The Implementation of Community Language Learning (CLL) in Teaching Speaking. This research is conducted on the second semester students of English Education Study Program who are taking Speaking For General Communication II on the second semester students at one of universities in Cianjur. This research aims to know how the implementation of CLL and to investigate its strengths and weaknesses, as well as to find out students' difficulties in learning speaking through CLL.

This research uses qualitative method which employs several techniques in collecting the data. The data are obtained by conducting observation and interview.
\end{abstract}

Keywords: Community Language Learning, teaching, and speaking

\section{Introduction}

Nowadays the importance of English mastery in our daily lives is undeniable and inevitable due to the rapid growth of science and technology. Almost every single thing in our lives uses English as its introductory language, so mastering English in this era is really necessary since it is the answer to meet the need of globalization and the development of science and technology. As a whole, there are four basic skills in English should be mastered namely listening, reading, writting, and speaking. Yet, speaking is always regarded as the most crucial one since speaking is frequently used in our daily lives or interactions. An effective 
teaching method or approach is needed because it plays an important role in transfering English speaking skill to students as well as the key to the success of teaching learning process of speaking. There are many methods or approaches used by lecturers in the classroom in teaching speaking in university, yet considered not so effective in stimulating students to be more active in speaking and to have more bravery and self confidence to use their own English although they may make more mistakes. Based on the depicted reality, the researcher feels chalenged to know how is the implementation of Community Language Learning (CLL) method, to investigate its strengths and weaknesses, as well as to find out students' difficulties in teaching Speaking for General Communication II on the second semester students at one of universities in Cianjur.

This study investigates the following questions:

1. How is the implementation of CLL method in teaching speaking on the second semester students of English Education Program at one of universities in Cianjur.

2. What are the strengths and weaknesses of CLL method in teaching speaking on the second semester students of English Education Program at one of universities in Cianjur.

3. What are students'difficulties in implementing of CLL method in teaching speaking on the second semester students of English Education Program at one of universities in Cianjur.

Regarding to the research questions, the purposes of the study are as follow:

1. To know how the implementation of CLL method in teaching speaking on the second semester students of English Education Program at one of universities in Cianjur.

2. To investigate the strengths and weaknesses of CLL method in teaching speaking on the second semester students of English Education Program at one of universities in Cianjur.

3. To find out students'difficulties in implementing CLL method in teaching speaking on the second semester students of English Education Program at one of universities in Cianjur.

This study was conducted on the second semester students of English Edation Program at one of universities in Cianjur. The concern of this study is the implementation, strengths, and weaknesses of CLL method in teaching speaking on the second semester students of English Education Program at one of universities in Cianjur.

This study is expected to give significance to the development of teaching and learning of speaking especially in a university where the research is conducted and generally in Indonesia. 
Hopefully, this study can be a solution on how to teach speaking effectively and also be a refferences for those who want to conduct research with similar topic. Practically, the research is expected to help lecturers of speaking course to provide some appropiate methods in teaching English speaking effectively.

\section{Literature Review}

Community Language Learning (also called Counseling Language Learning) was created by Charles A Curran, a Jesuit priest and professor of psychology, and Paul La Forge inspired by the humanistic psychology of Carl Rogers. It aims to remove the anxiety from learning by changing the relationship between the teacher and student. The Counseling-Learning educational model is applied to language learning, and in this form it became known as Community Language Learning seeks to encourage teachers to seetheir learners as whole persons, where their feelings, intellect, interpersonal relationships,protective reactions, and desire to learn are addressed and balanced.

CLL combines innovative learning tasks and activities. They include:

1. Translation: Learners form a small circle. A learner whispers a message ormeaning he or she wants to express, the teacher translates or interprets it in thetarget language, and the learner repeats the teacher's translation.

2. Group Work: Learners engage in various group tasks, such as small-groupdiscussion of a topic, preparing a conversation, preparing a summary of a topicfor presentation to another group, preparing a story that will be presented to theteacher and the rest of the class.

3. Recording: Learners record conversations in the target language.

4. Transcription: Learners transcribe utterances and conversations they haverecorded for practice and analysis of linguistic forms.

5. Analysis: Learners analyze and study transcriptions of target language sentencesin order to focus on particular lexical usage or on the application of particulargrammar rules.

6. Reflection and observation: Learners reflect and report on their experience of theclass, as a class or in groups. This usually consists of expressions of feelings -sense of one another, reactions to silence, concern for something to say, etc.

7. Listening: Learners listen to a monologue by the teacher involving elements theymight have elicited in class interactions. 
8. Free conversation: Learners engage in free conversation with the teacher or withother learners. This might include discussion of what they learned as well asfeelings they had about how they learned.

\section{Five Stages of CLL}

"The learner passes through five psychological stages as learning progresses, which Curran compares to the progressing from childhood to adulthood.

Birth: The learners know nothing of the target language, and are completely dependent on the teacher for everything they want to say.

Self: The learners start to get an idea of how the language works and to use it for themselves, but still seek the teacher's help.

Separate Existence: They start to use the language without referring to the teacher.

Adolescence: The learners continue to express themselves independently, but beingaware of gaps in their knowledge, and start to turn back to the teacher.

Independence: The learners continue their learning independently. They no longerneed the teacher, and may start to act as counselors for less advanced students.

\section{Speaking}

According to Chaney, speaking is ithe process of building and sharing meaning through the use of verbal and non-verbal symbols, in a variety of contexts.

While another expert, Theodore Huebner said Language is essentially speech, and speech is basically communication by sounds. And according to him, speaking is a skill used by someone in daily life communication whether at school or outside. The skill is acquired by much repetition; it primarily a neuromuscular and not an intellectual process. It consists of competence in sending and receiving messages.

From the above definition, it can be inferred that speaking is expressing ideas, opinions, or feelings to others by using words or sounds of articulation in order to inform, to persuade, and to entertain that can be learnt by using some teaching and learning methodologies.

\section{Teaching Speaking}


Speaking is a crucial part of second language learning and teaching. Despite its importance, for many years, teaching speaking has been undervalued and English language teachers have continued to teach speaking just as a repetition of drills or memorization of dialogues. However, today's world requires that the goal of teaching speaking should improve students' communicative skills, because, only in that way, students can express themselves and learn how to follow the social and cultural rules appropriate in each communicative circumstance.

\section{a. What is Teaching Speaking?}

What is meant by teaching speaking is to teach English language learners to:

1. Produce the English speech sounds and sounds patterns.

2. Use words and sentence stress, intonation patterns and the rhythm of the second language. Theodore Huebner, Audio Visual Technique in Teaching Foreign Language, (New York: Cambridge University Press, 1960) p. 5

3. Select appropriate words and sentences according to the proper socialsetting, audience, situation and subject matter.

4. Organize their thoughts in a meaningful and logical sequence.

5. Use language as a means of expressing values and judgments.

6. Use the language quickly and confidently with few unnatural pauses, which is called fluency. (Nunan 2003)

\section{b. How to Teach Speaking?}

Now many linguistics and English as second language (ESL) teachers agree on that students learn to speak in the second language by "interacting". Communicative language teaching and collaborative learning serve best for this aim. Communicative language teaching is based on real life situations that require communication. By using this method in ESL classes, students will have the opportunity of communicating with each other in the target language. In brief, ESL teachers should create a classroom environment where students have real-life communications, authentic activities, and meaningful tasks that promote oral language. This can occur when students collaborate in groups to achieve a goal or to complete a task. (Ayu Diyah Harni Susanti. 2017. Using Role Play In Teaching Speaking) 


\section{Research Methodology}

This research employed a qualitative research method that attempts to describe the implementation of Community Language Learning (CLL) method in teaching speaking on the second semester students of English Education Program at one of universities in Cianjur. This research took place on the second semester students of English Education Program at one of universities in Cianjur. The subjects of the research were 29 students of the second semester of English Education Program at one of universities in Cianjur. There were 6 male students and 23 female students. This class was chosen since they were taking Speaking for General Communication II course on the second semester.

In this research, the researcher uses two instruments for the data collection namely observation and interview.

\section{Observation}

According to Arikunto, observation is a technique of data collection which is done by conducting thorough research, as well as systematically recording. In observation activities, the researcher is not involved in teaching learning process done by the lecturer and students. The researcher only observes and monitors the teaching and learning process of speaking, and makes recording as well.

\section{Interview}

In order to dig deep information about the data, the researcher also performs an interview. According to Esterberg, interview is a meeting of two persons to exchange information and idea through questions and responses, resulting in communication and joint construction of meaning about a particular topic.

\section{Data Analysis}

In this research, the researcher describes, explains, understands, and interprets the objects or event to which researcher's data refers. Therefore, data analysis in every research was absolutely important to elicit the real and structural information based on research question. Data analysis is a process of resolving data into its constituent components, to reveal its characteristics 
elements and structure. In more detail step, the researcher also conducted some steps in analyzing the data obtained.

Relating to the interview data, the researcher listened to the recording of interview, transcribed into transcription, read the transcription, drew the points, and put it into general trend or theme. Almost the same interview data, in observation data, the researcher classified the data collected into general trend and theme based on the research question. Mathew and Huberman stated that there are several steps in this process, they are collecting data, data reduction, data display, drawing conclusion and verification. Here is the further explanation about the steps.

\section{Findings And Discussions}

This chapter discusses the data obtained from classroom observations and interviews. The data are used to answer all of the research questions. The first research question investigates the implementation of Community Language Learning (CLL) in teaching speaking on the second semester students, the second is the strengths and weaknesses of CLL in teaching speaking on the second semester students, and then the third explores students' difficulties in learning speaking through CLL method. The findings of each research question are discussed in depth in the following sections.

\section{The Implementation of Community Language Learning in Teaching Speaking.}

In this research, the classroom observations were conducted in a single class, particularly on the second semester students of English Education Program at one of universities in Cianjur,

and it was held three times exactly on Wednesday, 8, 15, 22 February 2017 based on schedule of the course.

Based on the observation results, the observer found that the students really enjoyed the learning process. It was reflected from their attitude and response during the course. The findings can be seen from observation results from the first meeting until the last meeting.

Data from interviews supported the data gained from the classroom observations. The interviews were held after the classroom observation had finished and involved three students. The researcher orally asked questions for three students. The interview explored all research questions well. 
In this case, the interviews were conducted at the end of the lesson in the last meeting on Wednesday, February 22nd, 2017 by using tape recorder. The interview lasted 3-5 minutes for each student. The interviewer selected the interviewee based on their high, middle, and low participation and motivation during the course.

The interviews concerning to the first research question related to the Implementation of Community Language Learning on the second semester students of English Education Program at one of universities in Cianjur. Based on the data from interviews, it was found that the students prefered CLL to any other methods. Most students enjoyed the learning process because CLL was fun and chalenging for them. It can be seen from their attitude and response during the course. The students were so enthusiastic when learning speaking.

Referring to the description above, it was inferred that the students got the steps of Community Language Learning (CLL) implemented completely but it still needed some improvements. Although the teaching-learning process of speaking implemented the steps of CLL completely, but a few of students were not so enthusiastic in the learning process. Students' seriousness could be seen from their participation in the learning process.

\section{The Strengths and Weaknesses of Community Language Learning in Teaching Speaking}

Based on the result of the classroom observations and interviews, there were four strengths and three weaknesses in implementing Community Language Learning in teaching speaking. First CLL method can encourage students to be more independent in doing their activities in the classroom, second this method also creates a pleasant and conducive atmosphere that is suitable for speaking learning environment, third this method increases students'selfconfidence especially for the slow learners, fourth this method allows students to have the freedom and inisiative as much as they want because they are actively involved in designing and formulating the learning process plan along with their lecturer.

Furthermore, there are three weaknesses that the researcher found in Community Language Learning. First CLL method tends to provide students with the low difficulty level learning, second the success of this method depends largely on the feedbacks of the lecturer as the counselor, third the evaluation test to see the progress that students have may be more complicated to be done than in ordinary classroom that does not use this method. 


\section{Students' Difficulties in Learning Speaking through Community Language Learning Method}

Based on the result of classroom observations and interviews, there are some students' difficulties in learning speaking through Community Language Learning, such as it is difficult for students to develop the topic for speaking activity, to express their opinions and ideas due to the lack of vocabulary and understanding of sentence structure, to respond the lecturer instruction or questions spontaneously because of the limited vocabularies, sentence structure and the lack of speaking practice, to make their ideas accomodated, to choose learning materials and activities in each meeting, and to understand the material delivered by lecturer.

\section{Conclusions And Suggestions}

This research reports the result of CLL implementation in teaching speaking on the second semester students of English Education Program at one of universities in Cianjur. The aims of the research are to know how the implementation of CLL in teaching speaking, to investigate the strengths and weaknesses of CLL, and to find out students' difficulties in learning speaking through CLL method. Based on the data analysis and discussions in the previous chapter, the researcher would like to draw conclusions as follows.

1. First, according to the data from the previous chapter shows that CLL method creates pleasant and conducive learning situation for students as well as creates good athmosphere in the classroom. The evidence can be seen from the classroom observation and interview results from their attitude and response to the lecturer in the classroom.

2. Second, refer to the data from the previous chapter shows strengths and weaknesses of CLL in teaching speaking. It can be shown from classroom observation and interview results that there are several strengths such as encouraging students to be more independent in doing their activities in the classroom, creating a pleasant and conducive atmosphere that is suitable for speaking learning environment, increasing students'selfconfidence especially for the slow learners, and allowing students to have the freedom

and inisiative as much as they want because they are actively involved in designing and formulating the learning process plan along with their lecturer. Furthermore, the result of classroom observations and interviews reveal that there are several weaknesses such as providing students with the low difficulty level learning, depending largely on the 
feedbacks of the counselor, and complicated evaluation test to see the progress of the students.

3. Third, based on the data from the previous chapter shows that students found the following difficulties such as developing the topic for speaking activity, expressing their opinions and ideas, responding the lecturer instruction or questions spontaneously,

choosing learning materials and activities in each meeting, and understanding the material delivered by lecturer.

\section{Suggestions}

The present study offers several practical suggestions. The suggestions can be drawn into two parts.

1. First, this research suggests several guidelines for lecturers who want to implement Community Language Learning method in their teaching, especially in teaching speaking. The research suggests that lecturers who use CLL method undertand its stages, procedures, and techniques, so the lecturer can implement it well in the classroom and also it can make the speaking learning process successful through alleviating anxiety, threat, and language problems that the students encounter in the learning procces.

2. Second, this research suggests that the researchers who have the same interests on CLL, to implement this method in teaching any other skills, disciplines, courses, and in different levels as well.

\section{References}

Arikunto, Suharsimi. 2006. Prosedur Penelitian Suatu Pendekatan Praktik, Jakarta: PT Rineka Cipta.

Banister, Peter. 2011. Qualitative Methods in Psychology. Open University Press.

Curran, Charles A. 1976. Counseling-Learning in Second Languages. Apple River Press.

Chaney, A. L and F L. Burk. 1998. Teaching Oral Communication. In Grades

K:2005. Boston: Allyn \& Bacon.

Esterberg, Kristin G. 2002. Qualitative Methods Ins Social Research. Mc Graw Hill, New York.

Miles, Matthew B. and A. Michael Huberman. 2004. Qualitative Data Analysis (terjemahan). Jakarta: UI Press.

Nunan, David. 2003. Practical English Language Teaching. New York: Mc Grow Hill Contemporary 
Nagaraj P. 2009. Application of Community Language Learning for Effective Teaching. The Modern Journal of Applied Linguistics.

Theodore, Huebner. 1960. Audio Visual Technique in Teaching Foreign Language. New York: Cambridge University Press. 